\title{
Remedial Siswa Melalui Met-Before Terhadap Pemahaman Materi Fungsi Komposisi Siswa Kelas X
}

\author{
Alifta Mardani ${ }^{1}$, Sumaji ${ }^{2}$ \\ ${ }^{1,2}$ Program Studi Pendidikan Matematika, Fakultas Keguruan dan Ilmu Pendidikan, Universitas Muhammadiyah Ponorogo, \\ Jl. Budi Utomo No. 10, Ponorogo, Jawa Timur, Indonesia \\ aliftamardani217@gmail.com
}

\begin{abstract}
This study aims to determine the met-before of the composition function material, and to see the completeness of student learning on the composition function material with remedial learning using met-before. The met-before is the previous student's experience. This research needs to be done because remedial learning activities have been carried out so far by generalizing the abilities of each student. In fact, the ability of each student is different and the causes of errors are also different. The method used in this study is a qualitative method with a qualitative descriptive type of research. The subjects in this study were students of class X SMA Negeri 1 Sambit. From the results of the pre-test, it is known that there are three characters or groups of students based on the understanding of the material composition function in terms of met-before. In the first group the students have not mastered the materials met-before from set to function and have not mastered the composition function material, the second group the students are only able to master the composition function material until the stage of calculating the composition function, and the third group the students are able to master the material met-before. from set to function and able to master composition function material. After being given remedial material, the students' ability to understand the composition function material, it was found that the student learning outcomes experienced completeness both in the composition function material.
\end{abstract}

Keywords: Remedial, Met-Before, Composition Function, Qualitative Descriptive

\begin{abstract}
Abstrak
Penelitian ini bertujuan untuk mengetahui met-before dari materi fungsi komposisi, dan untuk melihat ketuntasan belajar siswa pada materi fungsi komposisi dengan pembelajaran remedial menggunakan met-before. Metode yang digunakan pada penelitian ini yaitu metode kualitatif dengan jenis penelitian deskriptif kualitatif. Subjek pada penelitian ini yaitu siswa kelas X SMA Negeri 1 Sambit. Dari hasil pre-test diketahui bahwa terdapat tiga karakter atau kelompok siswa berdasarkan pemahaman materi fungsi komposisi ditinjau dari segi met - before. Pada kelompok pertama siswa belum menguasai materi-materi met-before dari mulai himpunan hingga fungsi dan belum menguasai juga materi fungsi komposisi, kelompok kedua siswa hanya mampu menguasai materi fungsi komposisi hingga tahap menghitung fungsi komposisi, dan kelompok ketiga siswa mampu menguasai materi metbefore dari mulai himpunan hingga fungsi dan mampu menguasai materi fungsi komposisi. Setelah diberikan materi remedial kemampuan siswa terhadap pemahaman materi fungsi komposisi diperoleh bahwa hasil belajar siswa mengalami ketuntasan baik pada materi fungsi komposisi.
\end{abstract}

Kata kunci: Remedial, Met - Before, Fungsi Komposisi, Deskriptif Kualitatif

Copyright (c) 2021 Alifta Mardani, Sumaji

$\triangle$ Corresponding author: Alifta Mardani

Email Address: aliftamardani217@gmail.com (Jl. Budi Utomo No. 10, Ponorogo, Jawa Timur, Indonesia)

Received 20 July 2021, Accepted 15 August 2021, Published 19 August 2021

\section{PENDAHULUAN}

Materi matematika bersifat hierarkis, apabila satu topik tidak terkuasai dengan baik maka materi selanjutnya siswa akan kesulitan (Ernest, 2004.). Sehingga semua materi yang diajarkan harus tuntas. Menurut Eryanti (2015) ketuntasan belajar adalah pencapaian hasil belajar yang telah ditentukan ukurannya serta dapat dipertanggungjawabkan sebagai syarat untuk kompetensi selanjutnya. Ketuntasan belajar matematika adalah level kemampuan siswa akan tujuan pembelajaran. Melalui belajar tuntas, siswa yang mampu menguasai materi pembelajaran diberikan pembelajaran pengayaan, sedangkan siswa yang belum mampu menguasai materi pembelajaran perlu diberikan pembelajaran perbaikan atau 
remedial. Menurut Ahmadi \& Supriyono (2004) remedial merupakan pembelajaran khusus yang digunakan untuk menyembuhkan, membetulkan dan memperbaiki agar menjadi baik. Remedial dilakukan agar setiap siswa berkembang secara penuh dan mencapai tujuan pembelajaran secara tuntas dan pembelajaran yang dilakukan menjadi bermakna. Namun, sebagian besar guru memberikan remedi kepada siswa secara sama rata. Menurut Hernadi, Ekayanti, \& Jumadi (2020) tuntutan hasil belajar matematika masih sebatas keterampilan siswa untuk mendapatkan jawaban akhir.

Menurut Tall (2004) menyatakan pengalaman sebelumnya sebagai met-before. Pengalaman sebelumnya mempengaruhi cara seseorang untuk memahami sesuatu yang baru. Menurut Sumaji \& Wahyudi (2020) siswa mampu mengaitkan antar konsep berdasarkan pengalaman yang diperoleh sebelumnya.Seperti yang telah diketahui bahwa matematika sendiri merupakan mata pelajaran dengan kumpulan materi-materi yang yang saling berhubungan atau berurutan. D. O. Tall (2008) mendefinisikan met-before sebagai fasilitas mental sekarang dari pengalaman khusus sebelumnya menurut individu tersebut. Menurut Nurhidayah (2015) proses belajar merupakan kunci dalam mencapai keberhasilan tujuan pembelajaran. Salah satu tujuan pembelajaraan matematika sekolah menengah menurut Permendikans nomor 22 tahun 2006 yaitu memahami konsep matematika, menjelaskan keterkaitan antar konsep dan mengaplikasikan konsep atau algoritma, secara luwes, akurat, efisien, dan tepat, dalam pemecahan masalah. Menurut Alfi \& Suhendar (2020) saat siswa mampu memahami konsep dari suatu materi maka siswa dapat menggunakan konsep tersebut dalam menyelesaikan berbagai macam permasalahan.

Materi yang digunakan dalam penelitian ini adalah fungsi komposisi, karena pada materi fungsi komposisi materi-materi penyusunnya lebih banyak dibandingkan dengan materi matematika kelas $\mathrm{X}$ yang lain, sehingga sangat cocok untuk mengetahui sejauh mana tingkat pemahaman met-before siswa mengenai materi fungsi komposisi. Selain itu, materi fungsi komposisi diajarkan pada jenjang sekolah menengah hingga bangku perkuliahan. Namun kenyataan dilapangan menunjukkan bahwa sebagian besar siswa masih kesulitan dalam mengerjakan materi fungsi komposisi. Berikut merupakan salah satu contoh jawaban siswa dalam menyelesaikan materi fungsi komposisi.

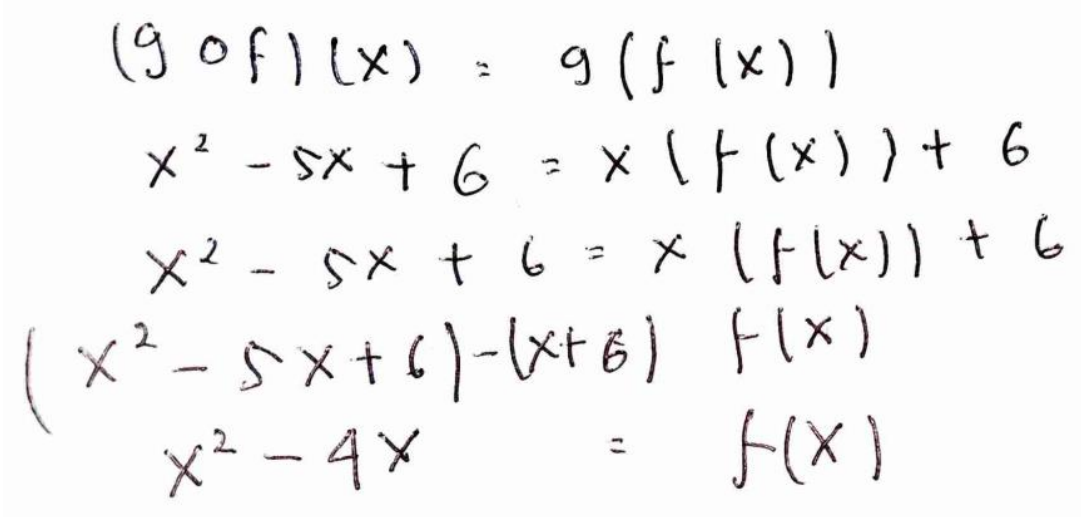

Gambar 1. Jawaban Siswa Dalam Mengerjakan Soal Fungsi Komposisi 
Remedial Siswa Melalui Met-Before Terhadap Pemahaman Materi Fungsi Komposisi Siswa Kelas X, Alifta Mardani, Sumaji

Berdasarkan gambar 1 di atas menunjukkan bahwa siswa mengalami kesulitan dalam mengerjakan materi fungsi komposisi. Hal ini dikarenakan siswa mengalami kesulitan dalam memahami dan mengaplikasikan rumus, selain itu siswa belum mampu memahami materi-materi met-before. Sehingga perlu diadakan remedial untuk memenuhi tujuan pembelajaran pada materi fungsi komposisi sehingga siswa tuntas dalam belajar fungsi komposisi.

Remedi yang sesuai dengan met-before pada materi fungsi komposisi yaitu disesuaikan dengan tingkat kelemahan siswa setiap siswa, siswa yang kesulitan terhadap materi himpunan maka akan diberikan pembelajaran remedial mulai dari materi himpunan hingga materi fungsi komposisi, siswa yang kesulitan materi persamaan linear diberikan pembelajaran materi persamaan linear hingga materi fungsi komposisi, siswa yang kesulitan materi persamaan kuadrat diberikan remedial muali dari persamaan kuadrat hingga materi fungsi komposisi, siswa yang kesulitan materi fungsi makan akan diberikan remedial materi fungsi dan materi fungsi komposisi, dan siswa yang kesulitan terhadap materi fungsi komposisi maka akan diberikan remedial materi fungsi komposisi. Untuk itu perlu dicari permasalah yang menjadi penyebab kesalahan siswa tersebut, sehingga dalam memberikan remedi sesuai dengan kemampuan siswa.

Met-before tidak sama dengan kemampuan awal peserta didik. Menurut Susilowati (2018) kemampuan awal siswa adalah suatu kemampuan yang telah dimiliki sebelum pembelajaran berlangsung yang merupakan prasyarat untuk mengikuti proses belajar selanjutnya. Kemampuan awal siswa merupakan prasyarat awal yang harus dimiliki siswa agar proses pembelajaran yang dilakukan siswa dapat berjalan dengan baik. Dapat disimpulkan bahwa kemampuan awal peserta didik yaitu kemampuan siswa pada materi prasyarat sebelum siswa belajar materi selanjutnya, sedangkan metbefore merupakan materi-materi penyusun dari materi tersebut.

Kegiatan pembelajaran remedial yang dilakukan selama ini dengan menyamaratakan kemampuan setiap siswa. Padahal kenyataannya kemampuan setiap siswa berbeda dan penyebab kesalahan juga berbeda. Kegiatan pembelajaran remedial yang disesuaikan dengan kemampuan met-before yaitu dengan melihat sejauh mana tingkat pemahaman siswa terhadap materi-materi penyusun fungsi komposisi. Materi met-before pada fungsi komposisi yakni himpunan, persamaan linear, persamaan kuadrat, dan fungsi. Penelitian ini bertujuan untuk mengetahui met-before dari materi fungsi komposisi dan untuk melihat ketuntasan belajar siswa pada materi fungsi komposisi dengan pembeajaran remedial menggunakan met-before. Berikut merupakan bagan alur kerangka konseptual atau kerangka berpikir pada penelitian ini. 


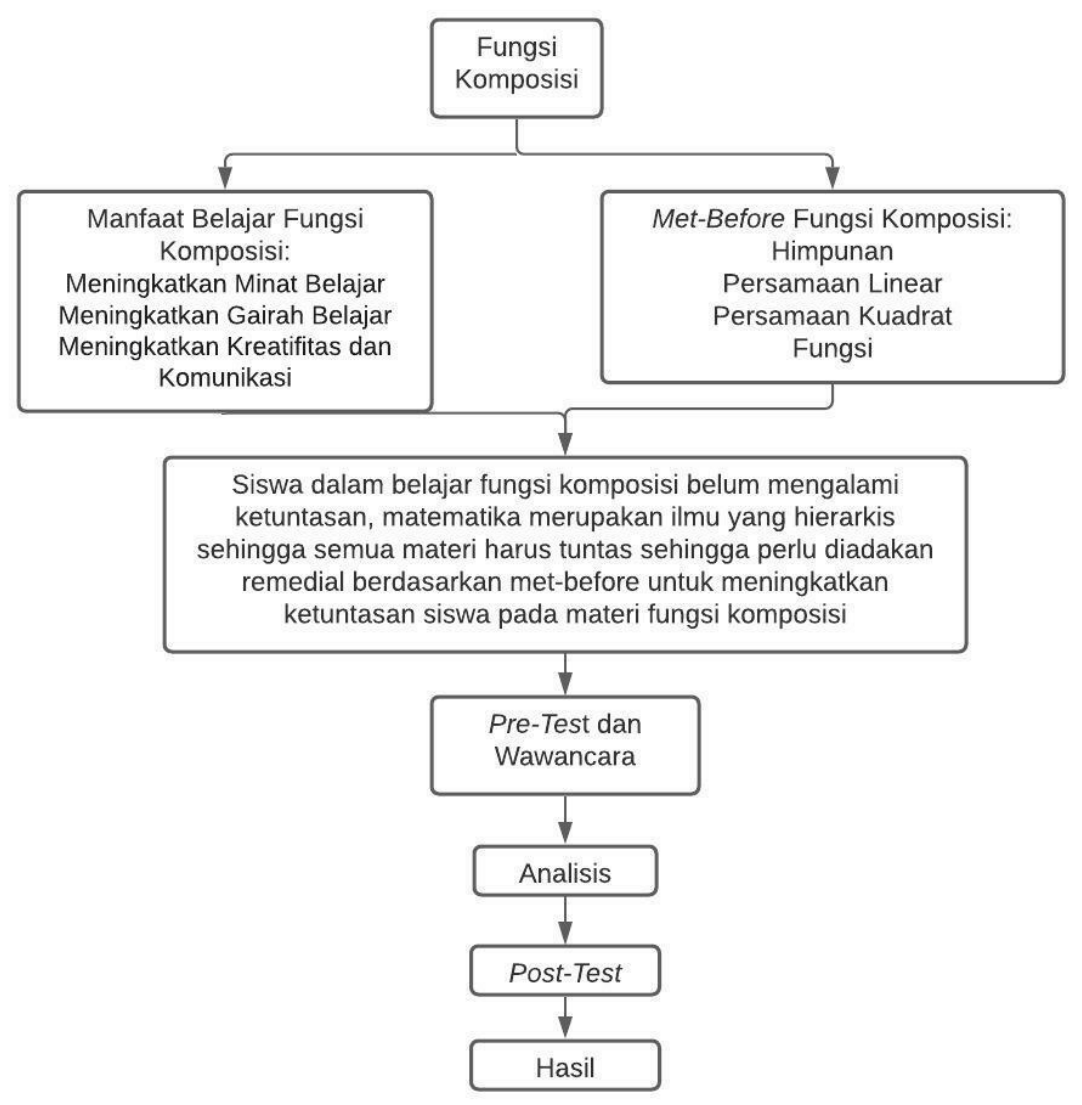

Gambar 2. Kerangaka Konseptual

\section{METODE}

Metode penelitian yang digunakan pada penelitian ini yaitu kualitatif dengan jenis penelitian deskriptif kualitatif. Menurut Sugiyono (2018) penelitian kualitatif adalah metode penelitian yang berlandaskan pada pengalaman dan ilmu yang pasti, dipakai untuk meneliti pada objek yang alami, peneliti pada penelitian ini merupakan instrument penting, teknik pengumpulan data dilakukan secara gabungan, analisis data bersifat induktif, dan hasil penelitian kualitatif lebih mengutamakan makna dari pada abstraksi. Moleong, J (2018) mengatakan bahwa pendekatan deskriptif kualitatif merupakan pendekatan penelitian yang data-datanya berupa kata-kata, gambar dan tidak memuat angka. Penelitian ini dilakukan pada bulan Juni 2021, subjek penelitian pada penelitian ini adalah siswa SMA Negeri 1 Sambit Ponorogo kelas X. Materi yang digunakan pada penelitian ini yaitu fungsi komposisi.

Instrumen yang digunakan yaitu lembar tes dan pedoman wawancara, ada dua jenis lembar tes yang digunakan yaitu instrumen pre-test dan post-test. Sebelum penelitian ini dilaksanakan, instrument penelitian divalidasi terlebih dahulu oleh dua orang validator, yaitu guru dan dosen. Setelah didapatkan instrumen penelitian yang valid dan instrument peneltian yang digunakan tidak perlu direvisi, maka instrumen penelitian siap digunakan.

Teknik pengumpulan data pada penelitian ini yaitu tes dan wawancara. Siswa diberikan pre-test dan diadakan wawancara mendalam dalam pre-test terdapat 3 soal dan dikerjakan dalam waktu 45 
menit, setiap soal siswa harus menjawab secara sistematis dan lengkap. Hal ini bertujuan untuk melihat sejauh mana tingkat pemahamaan siswa terkait materi met-before dan materi fungsi komposisi itu sendiri. Kemudian dianalisis hasil dari pre-test dan wawancara mendalam tersebut sehingga didapatkan karakteristik siswa atau kelompok siswa dengan kesulitan-kesulitan met-before pada materi fungsi komposisi. Dari hasil prêt-test dan wawancara mendalam diperoleh tiga karakteristik kesalahan siswa yaitu karakteristik yang pertaman yaitu siswa belum mampu memahami materi met-before dan materi fungsi komposisi, karakteristik yang kedua siswa mampu menghitung fungsi komposisi, dan karakteristik yang ketiga yaitu siswa mampu menguasai met-before dan materi fungsi komposisi.

Setelah dianalisis kemudian dilakukan pembelajaran remedial, setiap kelompok diberikan kegiatan pembelajaran remedial berdasarkan karakteristiknya. Proses pembelajaran remedial menggunakan metode belajar tutor sebaya atau peer teaching, hal ini dilakukan untuk membangun rasa percaya diri siswa sehingga mereka mampu menyampaikan gagasan mereka dan tidak malu dalam bertanya. Selain dengan tutor sebaya guru dapat menilai sejauh mana pemahaman siswa seperti yang dikatakan Suhendar \& Ekayanti (2018) seseorang yang paham dengan materi yang diajarkan, materi yang disampaikan akan lebih mudah diterima oleh orang yang diajari. Alasan lain melakukan kegiatan pembelajaran dengan metode tutor sebaya yaitu terkait efisiensi waktu, dengan tutor sebaya materimateri met-before dapat tersampaikan dalam waktu yang singkat.

Setelah kegiatan pembelajaran remedial kemudian siswa diberikan post-test terdapat 3 soal posttest dengan bobot soal yang sama seperti soal pre-test serta waktu pengerjaan soalnya sama seperti pretest yaitu 45 menit kemudian data yang diperoleh dianalisa. Wawancara untuk memperoleh informasi yang lebih dalam terkait kemampuan siswa pada materi fungsi komposisi. Analisis data yang digunakan yaitu data collection (pengumpulan data), data reduction (reduksi data), data display (penyajian data), dan conclusions drawring/verifying dengan menggunakan rumus, $\bar{X}=\frac{\sum X}{n}$ atau $\bar{X}=\frac{\text { Jumlah semua nilai }}{\text { banyaknya data }}$. Jika rata-rata setiap materinya $\geq 75$ maka siswa dikatakan tuntas, hal tersebut disesuaikan dengan Kriteria Ketuntasan Minimal (KKM).

\section{HASIL DAN DISKUSI}

Berdasarkan hasil dari pre-test dan wawancara diperoleh tiga karakteristik dalam melakukan kesalahan. Pada karakteristik pertama terdapat 5 orang siswa yang belum mampu memahami materi met-before dan materi fungsi komposisi. Pada karakteristik kedua terdapat 1 orang siswa yang hanya mampu mentukan fungsi komposisi. Pada karakteristik ketiga terdapat 6 siswa yang menguasai materi met-before dan materi fungsi komposisi.

1. Siswa belum mampu memahami materi met-before dan materi fungsi komposisi

Dari hasil pre-test menunjukkan bahwa 5 anak belum mampu menguasai materi met-before seperti materi himpunan, persamaan linear, persamaan kuadrat dan fungsi sehingga mengakibatkan siswa kesulitan dalam memahami materi fungsi komposisi. Dampak dari siswa yang belum menguasai met-before dan materi fungsi komposisi yaitu siswa kesulitan dalam menyelesaikan masalah terkait 
fungsi komposisi, meskipun hanya menentukan $\left(f^{\circ} g\right)(x)$. Siswa juga kesulitan dalam memahami soal sehingga siswa belum mampu menyelesaikan soal pre-test dengan baik.

2. Siswa mampu sampai tahap menghitung nilai fungsi komposisi

Berdasarkan hasil pre-test diketahui bahwa 1 orang siswa belum mampu menguasai materi metbefore fungsi komposisi mulai dari materi himpunan, persamaan linear, persamaan kuadrat dan fungsi. Sehingga siswa merasa kesulitan dalam menggambarkan grafik dari fungsi komposisinya dan menentukan daerah asal ataupun daerah hasilnya. Tetapi siswa tersebut mampu menghitung fungsi komposisi.

3. Siswa mampu menguasai beberapa materi met-before dan materi fungsi komposisi

Berdasarkan hasil pre-test diketahui bahwa terdapat 6 orang siswa yang mampu memahami materi fungsi komposisi dan materi met-before dari fungsi komposisi. Kesalahan yang dilakukan oleh meskipun terdapat beberapa kesalahan yang dilakukan seperti dalam menggambarkan grafik kebanyakan dari mereka belum menggambar grafiknya, ada juga salah dalam menggambarkan grafik dan ada siswa yang hanya mencari titik potong dengan bantuan titik $x$ saja tanpa mencari titik potong dengan bantuan titik $y$. Hal itu dikarenakan keterbatasan waktu dan kurang teliti dalam menggambarkan grafik.

Berdasarkan hasil pos-test dan wawancara diperoleh bahwa kemampuan siswa pada materi metbefore dan materi fungsi komposisi meningkatkan ketuntasan dalam belajar siswa, pada kelompok pertama siswa sudah mampu menentukan fungsi komposisi, menggambar grafik linear, dan sudah mampu menentukan daerah asal hanya saja pada materi persamaan linear siswa masih kesulitan dalam menggambarkan grafiknya. Pada kelompok kedua siswa sudah mampu memahami materi met-before dan materi fungsi komposisi, hal itu ditunjukkan dengan soal post-test yang terjawab dengan benar. Sedangkan pada kelompok ketiga, siswa sudah mampu memahami materi met-before dan materi fungsi komposisi hanya saja ada beberapa siswa yang menjawabnya secara tidak teliti, seperti $y=x+3$ sehingga nilai $x=3$, seharusnya nilai $x=-3$.

Tabel 1. Rata-rata Kemampuan Siswa Pada Pre-Test dan Post-Test

\begin{tabular}{|l|c|c|}
\hline \multicolumn{1}{|c|}{ Materi } & Pre-Test & Post-Test \\
\hline Himpunan & 50 & 100 \\
\hline Persamaan Linear & 25 & 85 \\
\hline Persamaan Kuadrat & 33 & 93 \\
\hline Fungsi & 50 & 100 \\
\hline Fungsi Komposisi & 58 & 100 \\
\hline
\end{tabular}

Dari tabel di atas menunjukkan bahwa kemampuan siswa dalam menyelesaikan soal pre-test pada materi himpunan hingga fungsi komposisi kurang dari Kriteria Ketuntasan Minimal (KKM) yaitu 75. Hal ini dikarenakan sebagian besar siswa masih kesulitan dalam menuliskan himpunan itu sendiri, sedangkan pada materi persamaan linear diakibatkan siswa tidak mampu menghitung nilai fungsi komposisi, selain itu siswa belum mampu membedakan persamaan linear dan persamaan kuadrat, serta kurangnya ketelitian siswa dalam mengerjakan. Pada materi persamaan kuadrat kesulitan yang dialami 
siswa hampir sama seperti pada materi persamaan linear, yaitu siswa masih kesulitan dalam mencari titik puncak dari grafik parabola, pada materi fungsi siswa belum mampu mencari daerah asal dan daerah hasil, selain itu sebagian besar siswa belum mampu menghitung nilai fungsi komposisi.

Pada hasil post-test diketahui bahwa siswa mampu mengerjakan soal post-test dengan baik, hal ini dapat terlihat dari tabel di atas. Kemampuan siswa pada materi met-before dan materi fungsi komposisi mencapai lebih dari KKM. Hanya saja, dikarenakan keterbatasan waktu sehingga siswa terburu-buru mengerjakan soal tersebut sehingga beberapa siswa kurang teliti dalam mengerjakannya. Hal tersebut mengakibatkan hasil keterpencapaian siswa dalam menyelesaikan soal post-test kurang maksimal pada beberapa materi met-before.

Pre-test dan wawancara mendalam dilakukan untuk mengukur sejauh mana tingkat pemahaman siswa. Pada saat pre-test 5 menit pertama siswa mengalami kesulitan untuk mengerjakan hal ini dikarenakan menurut mereka bobot soal yang diujikan pada pre-test terlalu sulit. Bahkan pada tahap memahami soal mereka merasa kesulitan. Ada juga siswa yang mengerjakan dengan baik dan lancar. Setelah dilakukan Pre-test dan wawancara mendalam maka dilakukan kegiatan pembelajaran remedial. Pembelajaran remedial disesuaikan dengan tingkat pemahaman siswa. Apabila siswa kesulitan pada materi met-before yang paling dasar yaitu himpunan maka siswa diberikan remedi atau perbaikan mulai dari materi himpunan, persamaan linear, persamaan kuadrat fungsi dan materi fungsi komposisi. Apabila siswa kesulitan dalam materi persamaan linear maka siswa diberika remedi berupa materi persamaan linear hingga materi fungsi komposisi, dan begitu pula siswa yang kesulitan pada materi fungsi komposisi maka diberikan remedi berupa fungsi komposisi.

Materi yang diajarkan pada kegiatan pembelajaran yaitu materi fungsi komposisi dan met-before dari materi fungsi komposisi. Materi paling dasar pada materi met-before adalah himpunan, setelah himpunan persamaan linear, persamaan kuadrat, dan fungsi. Pada materi himpunan sub materi yang diajarkan seperti pengertian himpunan, jenis-jenis himpunan, pengertian himpunan semesta, diagram venn, notasi dan anggota himpunan, cara menyatakan suatu himpunan, himpunan bagian, dan menentukkan banyaknya himpunan bagian dari suatuhimpunan. Pada materi persamaan linear sub materi yang diajarkan yaitu definisi dan contoh kalimat terbuka serta kalimat tertutup, persamaan linear satu variabel dan dua variabel serta menggambargrafik persamaan linear dua variabel. Pada materi persamaan kuadrat sub materi yang diajarkan yaitu definisi persamaan kuadrat dan cara menggambarkan grafik fungsi persamaan kuadrat. Pada materi fungsi sub materi yang dibahas yaitu definisi fungsi, notasi fungsi, serta fungsi komposisi itu sendiri.

Pada pembelajaran remedial menggunakan metode tutor sebaya, kegiatan pembelajaran dilaksanakan sesuai dengan RPP yang telah dibuat. Waktu pelasanaan pembelajaran remedial yaitu $2 \times 45$ menit. Sebelum memulai kegiatan pembelajaran peneliti melakukan apersepsi seperti peneliti meminta salah satu siswa untuk memimpin do'a kemudian mengabsen siswa. Selanjutnya peneliti memberikan motivasi kepada siswa dan review materi met-before dan fungsi komposisi, hal ini dilakukan untuk mengingat kembali materi-materi yang akan diajarkan. Setelah itu, dibentuk kelompok 
kecil dengan beranggotakan 5 siswa yang memiliki kemampuan yang heterogen pada setiap kelompoknya. Materi pada pembelajaran remedial yaitu himpunan, persamaan linear, persamaan kuadrat, fungsi, dan fungsi komposisi. Siswa yang memiliki karakteristik ketiga sebagai tutor untuk siswa yang memiliki pertama dan kedua. Siswa yang memiliki karakteristik kedua juga dapat menjadi tutor untuk siswa yang memiliki karakteristik pertama. Materi pada kegiatan pembelajaran remedial yaitu himpunan, persamaan linear, persamaa kuadrat, fungsi dan fungsi komposisi. Kemudaian siswa berdiskusi tentang materi-materi yang dipelajari. Setelah itu perwakilan kelompok menyampaikan hasil diskusinya, peneliti mengevaluasi apabila terjadi kesalahan konsep dan peneliti membuat kesimpulan dari pembelajaran tersebut. Setelah kegiatan pembelajaran remedial selesai, siswa diberikan soal posttest. Dalam soal post-test tersebut bobot soal sama seperti pre-test. Pada saat post-test dapat dilihat siswa lebih lancar dalam mengerjakan. Hanya saja ada beberapa siswa yang mengalami kesulitan untuk materi persamaan linear. Seperti saat menentukan titik potong sumbu $(x, y)$, ada siswa yang mencari titik potong sumbu $(x, y)$ menggunakan titik bantu $x$ saja, tetapi lupa untuk mencari titik bantu menggunakan titik $y$ sehingga grafik yang dibuat tidak sempurna. Selain itu siswa kurang teliti menghitung, seperti $y=x+3$ sehingga nilai $x=3$, seharusnya nilai $x=-3$. Selain materi persamaan linear, pada persamaan kuadrat ada siswa yang tidak menggambarkan grafiknya dengan alasan keterbatasan waktu.

Dari tabel dan uraian di atas dapat disimpulkan bahwa hasil pre-test dan post-test dengan dilakukannya remedial dengan met-before pada materi fungsi komposisi kemampuan siswa pada materi fungsi komposisi tersebut mengalami ketuntasan pada setiap materinya. Meskipun ada beberapa kesalahan yang diakibatkan kurang telitinya siswa dalam mengerjakkan soal post-test.

\section{KESIMPULAN}

Berdasarkan hasil dari penelitian dan pembahasan maka dapat disimpulkan bahwa terdapat tiga karakteristik siswa berdasarkan kemampuan pemahaman materi pada materi fungsi komposisi dan materi met-before dari materi fungsi komposisi saat dilakukan pre-test dan wawancara mendalam. Karakteristik yang pertama siswa belum menguasai materi-materi met-before mulai dari himpunan hingga fungsi dan belum menguasai juga materi fungsi komposisi, karakteristik kedua Siswa mampu sampai tahap menghitung nilai fungsi komposisi, dan karakteristik ketiga Siswa mampu menguasai beberapa materi met-before dan materi fungsi komposisi. Setelah diberikan pembelajaran remedial kemampuan siswa terhadap pemahaman materi fungsi komposisi hasil belajar siswa mengalami ketuntasan baik pada materi met-before maupun pada materi fungsi komposisi. Hal itu dapat dilihat dari hasil post-test, sebagian besar materi dapat dikuasai siswa dengan baik sehingga rata-rata setiap materi lebih dari KKM yaitu 75. Ketuntasan belajar pada materi fungsi komposisi tersebut dikarenakan kegiatan pembelajaran remedial yang dilakukan sesuai tingkat kesulitan siswa berdasarkan karakteristik siswa. Siswa dengan karakteristik pertama diberikan pembelajaran remedial mulai dari materi himpunan hingga materi fungsi komposisi, siswa dengan karakteristik yang kedua diberikan pembelajaran 
Remedial Siswa Melalui Met-Before Terhadap Pemahaman Materi Fungsi Komposisi Siswa Kelas X, Alifta Mardani, Sumaji

remedial mulai dari himpunan hingga fungsi, sedangkan siswa dengan karakteristik yang ketiga diberikan pembelajaran sesuai dengan materi met-before yang belum dikuasai.

\section{UCAPAN TERIMA KASIH}

Peneliti memanjatkan rasa syukur kepada Allah SWT, karena telah memberikan kelancaran dalam penelitian dan menyusun artikel ini hingga selesai. Peneliti mengucapkan terimakasih kepada orang tua dan keluarga yang selalu memberikan dukungan penuh kepada penulis. Penulis ucapkan terimakasih juga kepada dosen pembimbing saya yakni Dr. Sumaji, M.Pd. yang telah memberikan bimbingan serta arahan kepada saya dalam menyelesaikan penelitian dan artikel ini. Tak lupa juga kepada kepala sekolah dan guru-guru SMA Negeri 1 Sambit sahabat-sahabat yang telah mendukung penelitian dan artikel ini.

\section{REFERENSI}

Ahmadi, A., \& Supriyono, W. (2004). Psikologi Belajar. Jakarta: PT. Reneka Cipta.

Alfi, S., \& Suhendar, U. (2020). PENERBITAN ARTIKEL ILMIAH MAHASISWA Universitas Muhammadiyah Ponorogo. Penerapan Model Problem Based Learning Berbantu Strategi Game Mazelabirin Dan Puzzle Untuk Meningkatkan Pemahaman Konsep Matematika Siswa Kelas X MIPA 3 SMA N 1 Badegan, 2(2020), 12-20. https://doi.org/10.24269/ed.v4i1.425

Ernest, P. (n.d.). The Philosophy of Mathematics Education (2004th ed.). Taylor \&Francis Group.

Eryanti, I. (2015). Pengaruh Strategi Belajar Peta Konsep Terhadap Ketuntasan Belajar Matematika Siswa. Jurnal Pendidikan Matematika \& Matematika, 1(2), 59-70.

Hernadi, J., Ekayanti, A., \& Jumadi. (2020). Some diagnostics learning problems on basic arithmetic skills of junior high school students. Journal of Physics: Conference Series, 1613(1). https://doi.org/10.1088/1742-6596/1613/1/012060

Moleong, J, L. (2018). Metodologi PenelitianKualitatif(Revisi). Bandung: Remaja Rosdakarya.

Nurhidayah, D. A. (2015). Pengaruh Motivasi Berprestasi dan Gaya Belajar Terhadap Prestasi Belajar Siswa Pada Mata Pelajaran Matematika SMP. Jurnal Dimensi Pendidikan Dan Pembelajaran, 3(2), 13-24. https://doi.org/http://dx.doi.org/10.24269/dpp.v3i2.83

Permendikans, nomor 22 tahun 2006. (2006). Peraturan Menteri Pendidikan Nasional Republik Indonesia Nomor 22 Tahun 2006 tentangStandar Isi UntukSatuan Pendidikan Dasar dan Menengah. jakarta.

Sugiyono. (2018). Metode Penelitian Kuantitatif Kualitatif dan $R \& D$. Bandung: Alfabeta.

Suhendar, U., \& Ekayanti, A. (2018). Problem Based Learning Sebagai Upaya Peningkatan Pemahaman Konsep Mahasiswa. Jurnal Dimensi Pendidikan Dan Pembelajaran, 6(1), 15-19. Retrieved from http://journal.umpo.ac.id/index.php/dimensi/article/view/815

Sumaji, S., \& Wahyudi, W. (2020). Refleksi Pembelajaran Matematika SMK Muhammadiyah 1 Ponorogo Pada Materi Persamaan dan Pertidaksamaan Linear Mutlak. Jurnal Cendekia : Jurnal Pendidikan Matematika, 4(2), 746-755. https://doi.org/10.31004/cendekia.v4i2.281 
Susilowati P. J., R. N. (2018). Hubungan Kemampuan Awal terhadap Kemampuan Berpikir Kritis Matematika pada Siswa kelas VII SMP Pesantren Immim Putri Minasatene. Mosharafa: Jurnal Pendidikan Matematika, 7(1), 199-206.

Tall, D. (2004). Thinking through three worlds of mathematics. Proceedings of the 28th Conference of the International Group for the Psychology of Mathematics Education., 4, 281-288.

Tall, D. O. (2008). The transition to formal thinking in mathematics. Mathematics Education Research Journal, 20(2), 5-24. https://doi.org/10.1007/BF03217474 